\author{
Military Technical College \\ Kobry El-Kobbah, \\ Cairo, Egypt
}

14th International Conference on

Applied Mechanics and

Mechanical Engineering.

\title{
Experimental Study on a Diesel Engine Fuelled with New and Used Cooking Oil Methyl Ester
}

\author{
By \\ Ahmed Mohamed Rashad* \\ Abstract:
}

The results of the performance of a compression ignition engine (direct injected, 4-stroke 1cylinder engine) by using methyl ester (biodiesel) from fresh and used vegetable oil have been presented in this paper along with the performance using petroleum diesel fuel. Shortterm engine performance tests were conducted using methyl ester oil from new and used cooking oil. The engine performance parameters studied were power output, maximum incylinder pressure, brake specific fuel consumption, brake thermal efficiency and exhaust gas temperature by using diesel fuel alone and the above mentioned biodiesel fuel. The emissions measured were $\mathrm{CO} 2, \mathrm{CO}$.

Data thus obtained were analyzed and compared with those of diesel fuel. The in-cylinder pressure was observed to be about $7 \%$ higher as compared to that with diesel fuel. The exhaust gas temperature was observed to increase in case of biodiesel. Significant reduction (about $80 \%$ ) in CO emission was observed as compared to that with diesel fuel. The CO2 emission from the biodiesel (obtained from fresh cooking oil) fuelled engine was slightly higher than diesel fuel as compared with diesel. While significant reduction (about 48\%) in CO2 emission from the biodiesel (obtained from used cooking oil) fuelled engine was observed as compared to that with diesel. At the same time brake thermal efficiency was observed to be lower (with about 16\%) as compared to that with pure diesel. Brake specific fuel consumption was higher as compared with diesel fuel especially at low load.

Keywords:

Vegetable oil fuel, alternative fuel, methyl ester, biodiesel 


\author{
* Egyptian Armed Forces \\ ** Benha High Technology Institute, Benha, Egypt \\ *** College of Engineering, Cairo University, Cairo, Egypt
}

\title{
1. Introduction:
}

The large increase in the world energy demand in recent years has resulted in great demand for petroleum products. With crude oil reserves estimated to last for few decades, there has been an active search for alternate fuels. The depletion of crude oil would cause a major impact on the transportation sector. Of the various alternate fuels under consideration, biodiesel, derived from vegetable oils, is the most promising alternative fuel to diesel [1]. Vegetable oil esters (biodiesel) have gained good promise and suitability for their use in compression ignition engine [2].

Biodiesel, derived from vegetable oils, is the most promising alternative fuel to diesel due to the following reasons [1].

1. Biodiesel can be used in the existing engine without any modifications.

2. Biodiesel is made entirely from vegetable sources; it does not contain any sulfur, aromatic hydrocarbons, metals or crude oil residues.

3. Biodiesel is an oxygenated fuel; emissions of carbon monoxide and soot tend to reduce.

4. Unlike fossil fuels, the use of Biodiesel does not contribute to global warming as $\mathrm{CO} 2$ emitted is once again absorbed by the plants grown for vegetable oil /biodiesel production. Thus $\mathrm{CO} 2$ balance is maintained.

5. The Occupational Safety and Health Administration classifies biodiesel as a nonflammable liquid.

6 . The use of biodiesel can extend the life of diesel engines because it is more lubricating than petroleum diesel fuel.

7. Biodiesel is produced from renewable vegetable oils/animal fats and hence improves the fuel or energy security and economy independence

A lot of research work has been carried out to use vegetable oil both in its neat form and modified form. Studies have shown that the usage of vegetable oils in neat form is possible but not preferable. The high viscosity of vegetable oils and the low volatility affects the atomization and spray pattern of fuel, leading to incomplete combustion and severe carbon deposits, injector choking and piston ring sticking [3]. The methods used to reduce the viscosity are:

* Blending with diesel

* Emulsification

* Pyrolysis

* Transesterification

Among these, the transesterification is the commonly used commercial process to produce clean and environmental friendly fuel. Methyl / ethyl esters of sunflower oil, rice bran oil palm oil, mahua oil [2], jatropha oil [4], karanja oil, soybean oil, rapeseed oil [5] and rubber seed oil have been successfully tested on compression ignition enginges. engines and their performance has been studied. The sunflower oil, soybean oil and palm oil are edible oils and also, are expensive. Hence they are not suitable for use as feedstock for biodiesel production in economical way. The non-edible oils such as jatropha oil and karanja oil, even though attractive due to their low cost, requires considerable amount of land and time for cultivation. 
These uncertainties can prevent large-scale production and marketing of biodiesel. Used cooking oils provide a viable alternative to diesel, as they are easily available. These contain some degradation products of vegetable oils and foreign material. These impurities can be removed by heating and filtration. Hence this does not prevent its usage as feedstock for biodiesel production. It has been reported that the cetane number of used cooking oil methyl ester is around 49 and it demonstrates its potential to replace diesel. The objective of this work is to use methyl, esters (biodiesel) from new and used vegetable oil as fuel for direct injection diesel engine and to find the performance and exhaust emissions.

\section{Fuel Preparation::}

Biodiesel is the mono-alkyl ester of long chain fatty acids derived from vegetable oil. Biodiesel depends on the source of raw materials and the chemical composition. Composition of vegetable oils within the spices also varies from one geographical area to another. Transesterification is the transformation of one type of an ester into another type of ester known as biodiesel. To prepare the fuel for the present work $200 \mathrm{ml}$ of methyl alcohol and $3.5 \mathrm{~g}$ of sodium hydroxide (lye) were taken in a beaker and mixed well for $5 \mathrm{~min}$. To this one liter of vegetable oil was added and stirred for $15 \mathrm{~min}$ with heating to $65^{\circ} \mathrm{C}$. The stirring was stopped and then the glycerin was allowed to settle down in the beaker. Later, the biodiesel (ester) was separated by washing and then boiled to remove the moisture. The transestrification reaction is [6]
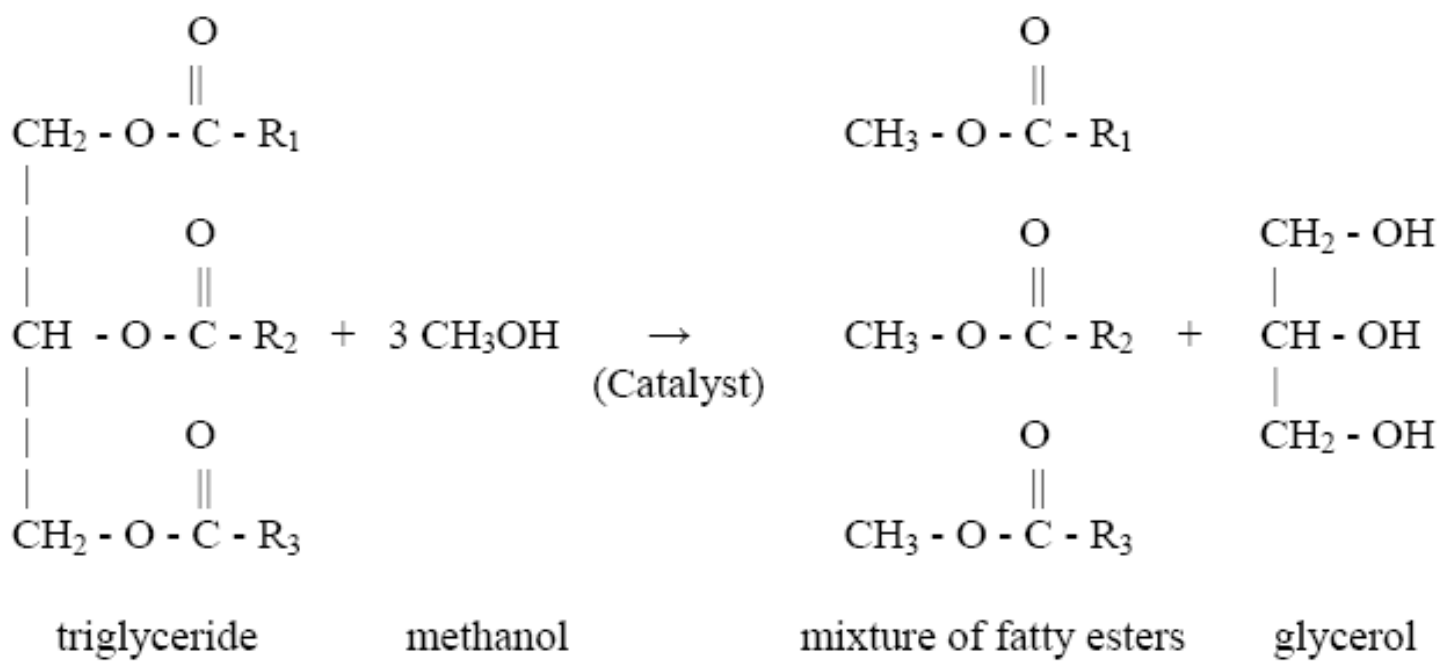

Where R1, R2, and R3 are long chains of carbons and hydrogen atoms, sometimes called fatty acid chains.

The properties of the produced biodiesel were determined. The measured properties along with the properties of the diesel fuel are given in table (1)

\section{Experimental Set-Up and Procedures:}

Experiments using pure diesel oil and biodiesel produced from new and used cooking oil were conducted on a constant speed single cylinder, direct injection, air cooled diesel engine 
(type Deutz-F1L-511) maximum of $8.3 \mathrm{HP}$ at $1500 \mathrm{rpm}$. The diesel engine is coupled with an electric generator which transforms the mechanical work of the engine into an electrical measurable load. The output of the diesel generator set is delivered on an electrical board with a calibrated current and voltage gauges to measure the value of the current and volt at each load. The control panel is connected to high wattage lamp bank. The rate of fuel consumption is measured by recording the time of consuming a certain volume of fuel. Engine speed is measured by measuring the number of revolutions of the crankshaft per minute. A shaft encoder (type WDG58B- G24) is used for this purpose and for measuring the crank angle degree. In-cylinder pressure is one of the internal parameters, which is measured to show the effect of varying operating conditions on the engine. A self-generating, water cooled piezoelectric sensor (type PCB-112B11) is used in measuring the in-cylinder pressure of the engine. A calibrated $\mathrm{K}$ - type thermocouple probe $(\mathrm{Ni} \mathrm{Cr} / \mathrm{Ni} \mathrm{Al})$ with a fiberglass insulated pair wire is used to measure the temperature variation of the exhaust gases. A gas analyzer UEI (Auto 4-2) was used for measuring the exhaust gases concentrations. Figure (1) shows the schematic drawing for the test rig and the locations of the measuring devices The baseline test was conducted using diesel fuel alone for its comparison with the performance of biodiesel fuels. The engine was started and run till it attained the speed little higher than $1500 \mathrm{rpm}$. Then the speed was adjusted exactly to $1500 \mathrm{rpm}$ by adjusting the fuel control lever. The load on the engine was gradually applied with the help of electrical lamp bank. The speed for all the observations was kept constant at $1500 \mathrm{rpm}$. For the stabilization of measuring parameters at each load change and at the start of each test a time period of 10 minutes and 20 minutes was respectively allowed. One set of observations consists of measurements relating to (i) reading of voltage and current, (ii) time for $50 \mathrm{cc}$ of fuel consumption, (iii) reading for the exhaust temperature, (iv) maximum in cylinder pressure, (v) $\mathrm{CO} 2, \mathrm{CO}$ and, $\mathrm{HC}$ emissions. The following parameters were calculated to predict and compare the engine performance such as (i) brake power output in kW, (ii) engine specific fuel consumption in $\mathrm{kg} /(\mathrm{kW} . \mathrm{h}$ ) (iii) brake thermal efficiency.

\section{Results and Discussion}

The results of the present investigation are presented in figures 2 through 8 . The fuel consumption rate of the engine was increased in case of biodiesel and as shown in figure. 2. The fuel consumption was about 4 per cent higher than that of diesel. This may be due to higher specific gravity and lower calorific value of the biodiesel fuel as compared with diesel fuel. The calorific value of the biodiesel was about 8 per cent lower than that of diesel fuel.

The specific fuel consumption was calculated by fuel consumption rate divided by the rated power output of the engine. The specific fuel consumption of the engine was increased in case of biodiesel as shown in figure (3). The percent increase in specific fuel consumption was up to 26 percent.

Figure (4) shows that brake thermal efficiency of biodiesel is lower compared to that of diesel. It was observed that the brake thermal efficiency at higher loads was slightly low as compared to that with pure diesel. The percent decrease in brake thermal efficiency was up to 16 percent at high load. Since the engine is operated under constant injection advance and biodiesel has a smaller ignition delay, combustion is initiated much before TDC (top dead center) is reached. This increases compression work and more heat loss and thus reduces 
the brake thermal efficiency of the engine. This can also be explained by the fact that maximum efficiency is obtained when most of the heat is released close to TDC. The start of heat release much before TDC for biodiesel results in larger deviation from the ideal cycle and hence lower thermal efficiency is recorded [1].

The amount of $\mathrm{CO}$ emission was lower in case of biodiesel fuels than diesel because of the fact that biodiesel contained 11 per cent oxygen molecules. This may lead to complete combustion and reduction of $\mathrm{CO}$ emission in biodiesel fuelled engine [1].

Figure (5) shows that carbon monoxide emissions are greatly reduced with biodiesel. The emission of $\mathrm{CO}$ is reduced by $34 \%$ (fresh cooking oil) and by $80 \%$ for (used cooking oil) when compared to diesel at rated load condition. $\mathrm{CO}$ is predominantly formed due to the lack of oxygen. Since biodiesel is an oxygenated fuel, it leads to better combustion of fuel resulting in the decrease in $\mathrm{CO}$ emission. Reduction in $\mathrm{CO}$ emissions is a strong advantage in favor of biodiesel [1].

On the other hand figure (6) shows that carbon dioxide emission was reduced with biodiesel from used cooking oil.

Figure (7) illustrates that the peak pressure is slightly higher for biodiesel fuels when compared to that of diesel. This is due to the lower ignition delay of biodiesel. The oxygen content of biodiesel, which results in better combustion, may also result in higher peak pressure compared to diesel [1].

Figure (8) illustrates that the exhaust gas temperature is higher for biodiesel. This may be due to the oxygen content of the biodiesel, which improves combustion and thus may increase the exhaust gas temperature [1].

Table (1): Properties of diesel fuel and biodiesel

\begin{tabular}{|c|c|c|c|c|c|}
\hline No. & Test & Test Method & $\begin{array}{c}\text { Biodiesel } \\
\text { (Fresh cooking oil) }\end{array}$ & $\begin{array}{c}\text { Biodiesel } \\
\text { (used cooking oil) }\end{array}$ & $\begin{array}{c}\text { Diesel } \\
\text { fuel }\end{array}$ \\
\hline 1 & $\begin{array}{c}\text { Relative density } \\
60 / 60 \mathrm{~F}\end{array}$ & ASTM D1298 & 0.8897 & 0.8927 & 0.837 \\
\hline 2 & $\begin{array}{c}\text { Kinematic Viscosity } \\
\text { Cst at 40 oC }\end{array}$ & ASTM D445 & 5.571 & 6.287 & 2.96 \\
\hline 3 & Carbon residue \% & ASTM D189 & ----- & ----- & 0.02 \\
\hline 4 & Ash content \% & ASTM D482 & ---- & --- & 0.005 \\
\hline 5 & $\begin{array}{c}\text { Flash point oC } \\
\text { (Pensky Martin) oC }\end{array}$ & ASTMD 93 & 161 & 167 & 62 \\
\hline 6 & Pour point OC & ASTMD 97 & -3 & -9 & 0 \\
\hline 7 & Cetane No & ASTM D4737 & N/A & N/A & 51.9 \\
\hline 8 & Heating value MJ/kg & ASTM D4868 & 40 & 40.7 & 44.1 \\
\hline 9 & Sulpher content \% & ASTM D2622 & 0.1198 & 0.115 & 0.5 \\
\hline 10 & Cloud point OC & ASTM D2500 & 2.52 & 1.5 & -7 \\
\hline 11 & Fire point OC & IB 36 & 183 & 186 & ----- \\
\hline
\end{tabular}


Table (2): Location number and names of the measured parameters

\begin{tabular}{|c|c|}
\hline Location & Measured parameter \\
\hline 1 & Fuel flow rate \\
\hline 2 & $\begin{array}{c}\text { Engine speed \& crank } \\
\text { angle }\end{array}$ \\
\hline 3 & In-cylinder pressure \\
\hline 4 & $\begin{array}{c}\text { Exhaust gases } \\
\text { temperature }\end{array}$ \\
\hline 5 & $\begin{array}{c}\text { Exhaust gases } \\
\text { concentrations }\end{array}$ \\
\hline
\end{tabular}

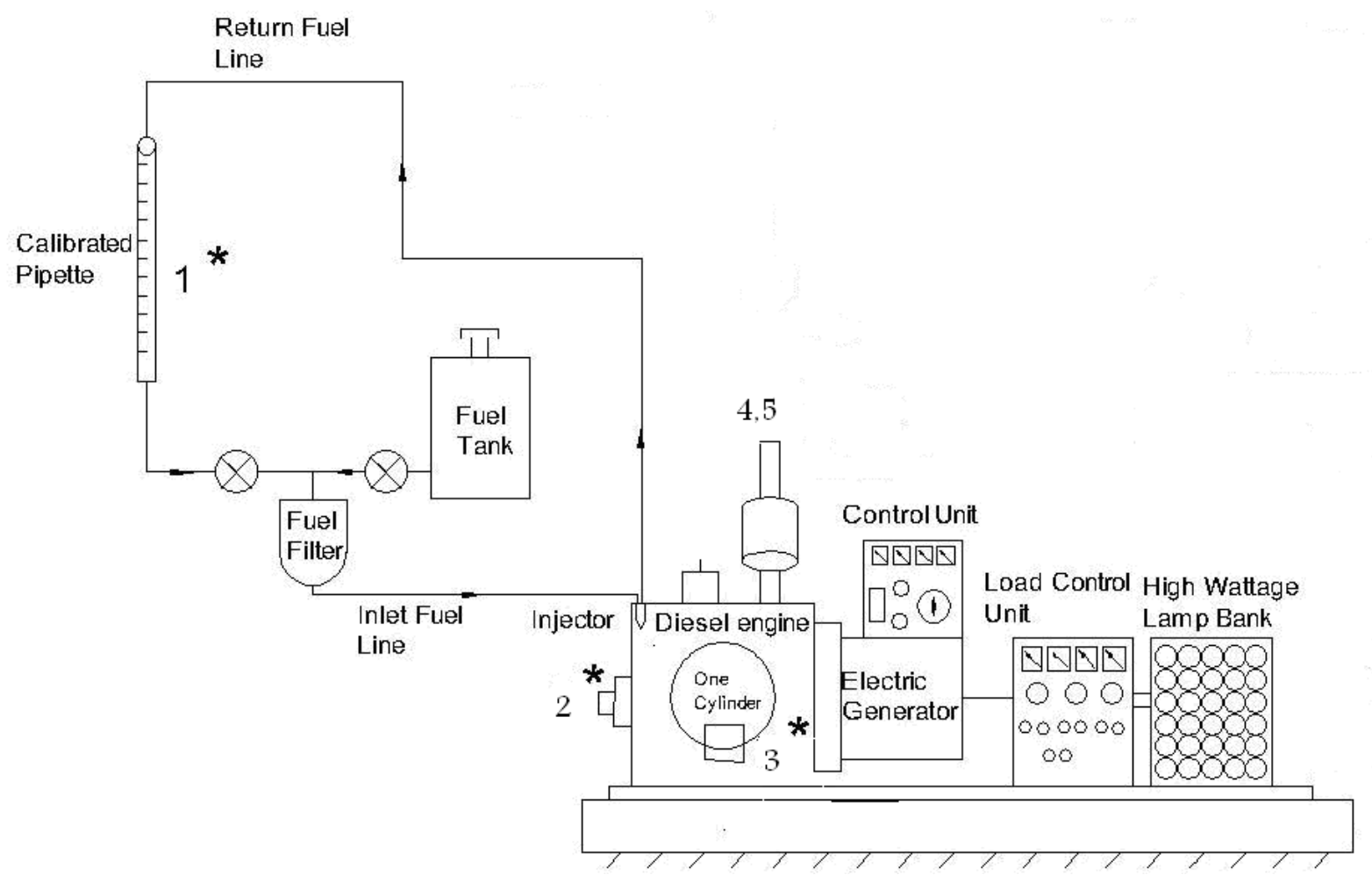

Figure (1): Schematic drawing for the location of the measuring devices 


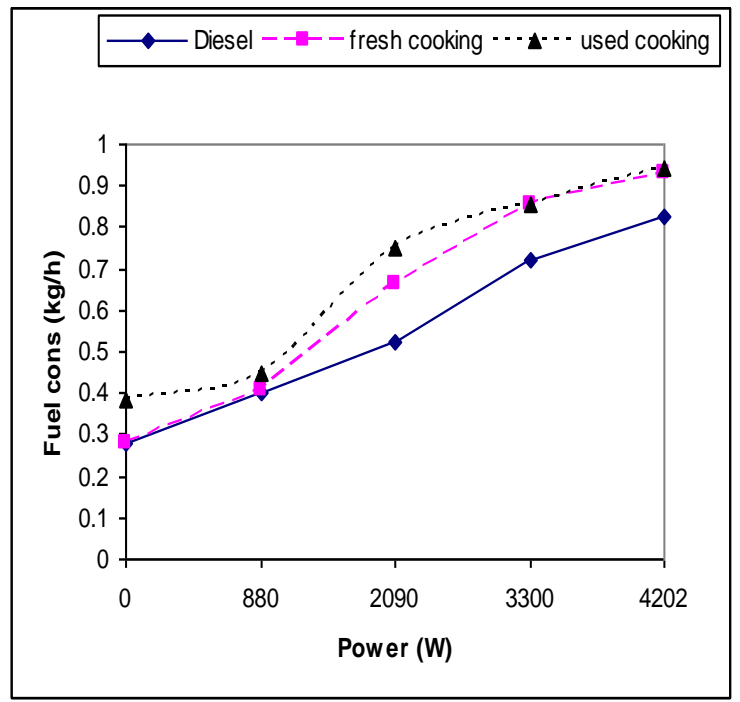

Figure (2): comparison of fuel consumption for biodiesel and diesel fuel

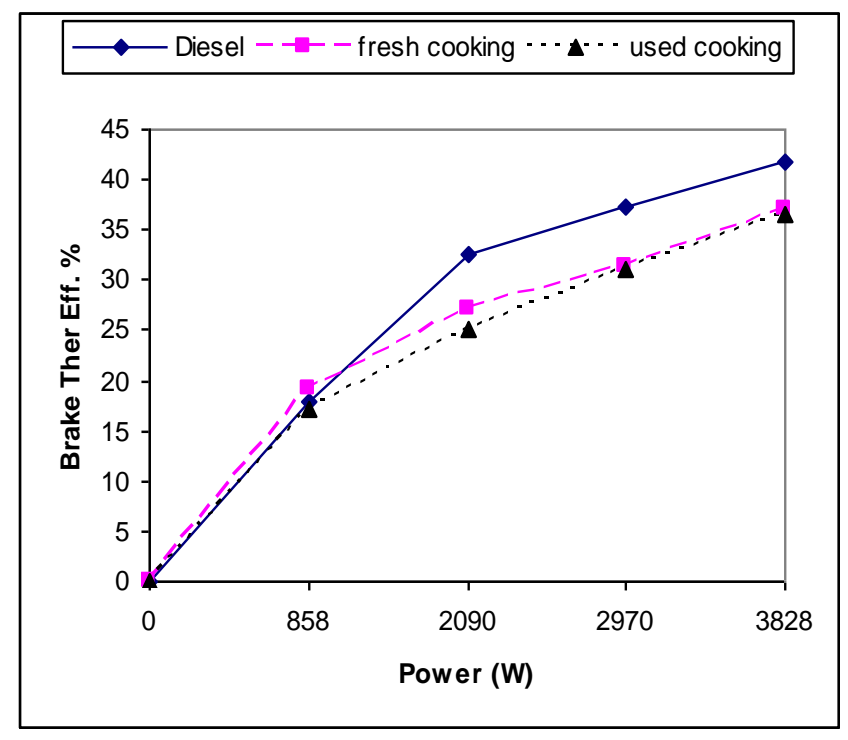

Figure (4): comparison of brake thermal efficiency for biodiesel and diesel fuel

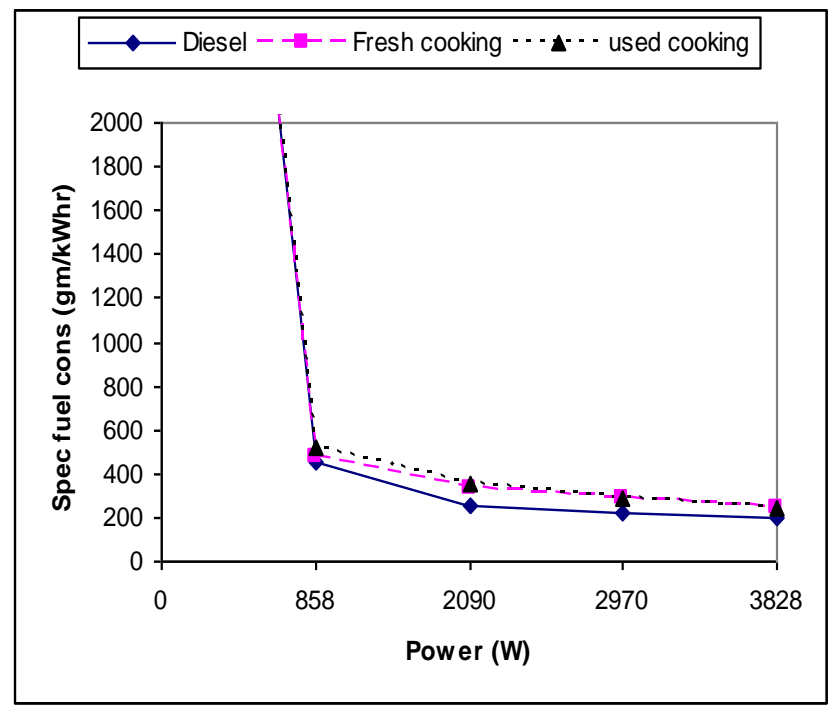

Figure (3): comparison of specific fuel consumption for biodiesel and diesel fuel

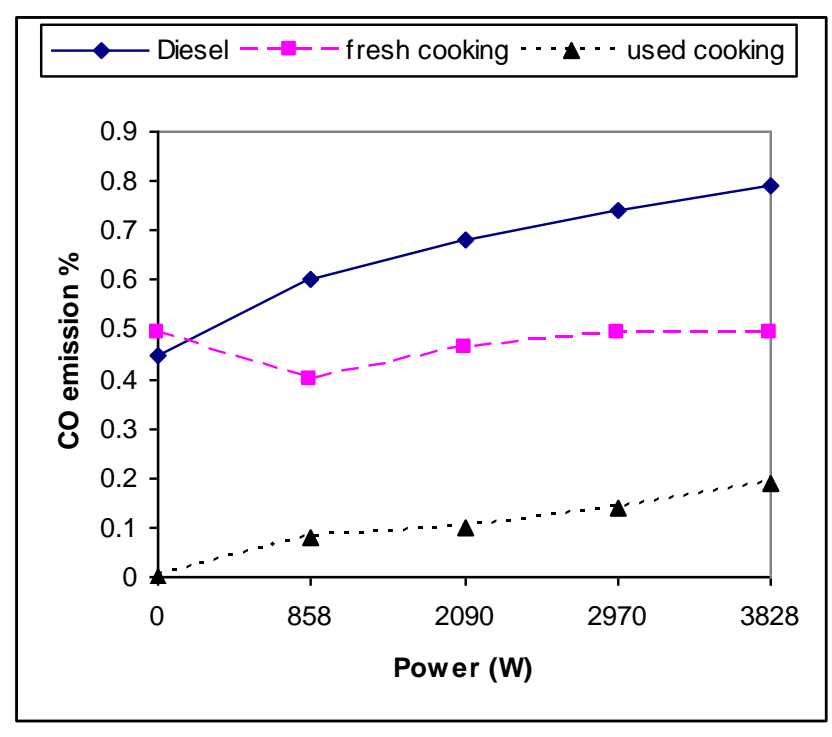

Figure (5): comparison of carbon monoxide emission for biodiesel and diesel fuel 


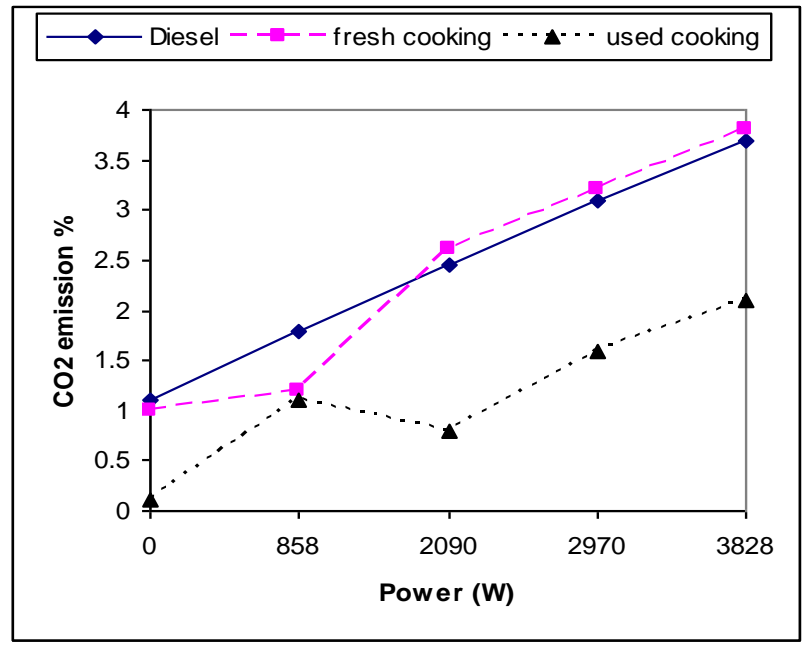

Figure (6): comparison of carbon dioxide emission for biodiesel and diesel fuel

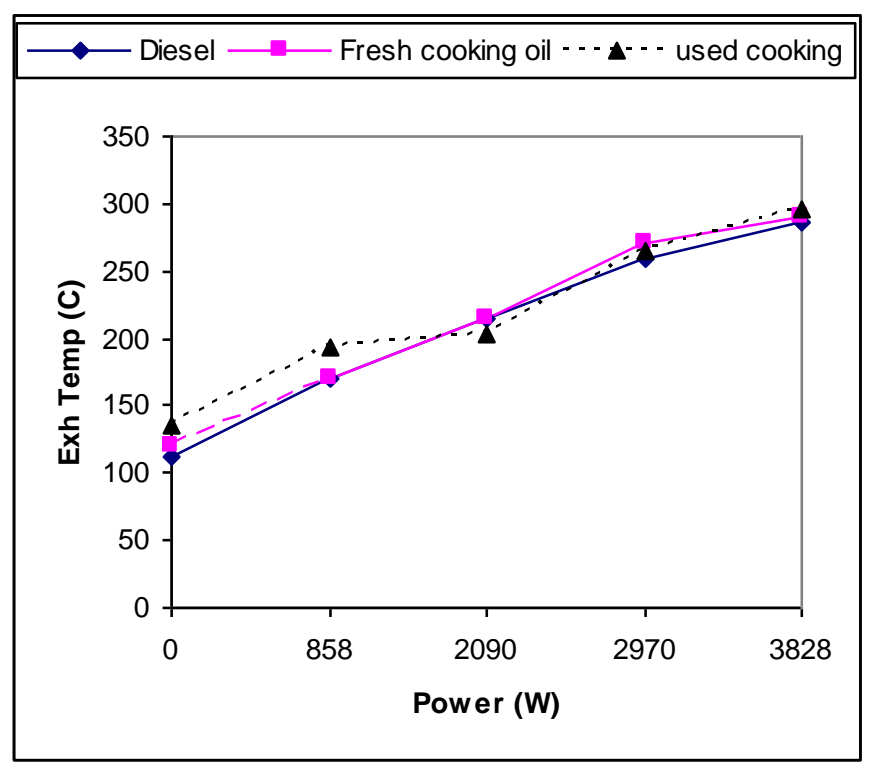

Figure (6):comparison exhaust temperature for biodiesel and diesel fuel

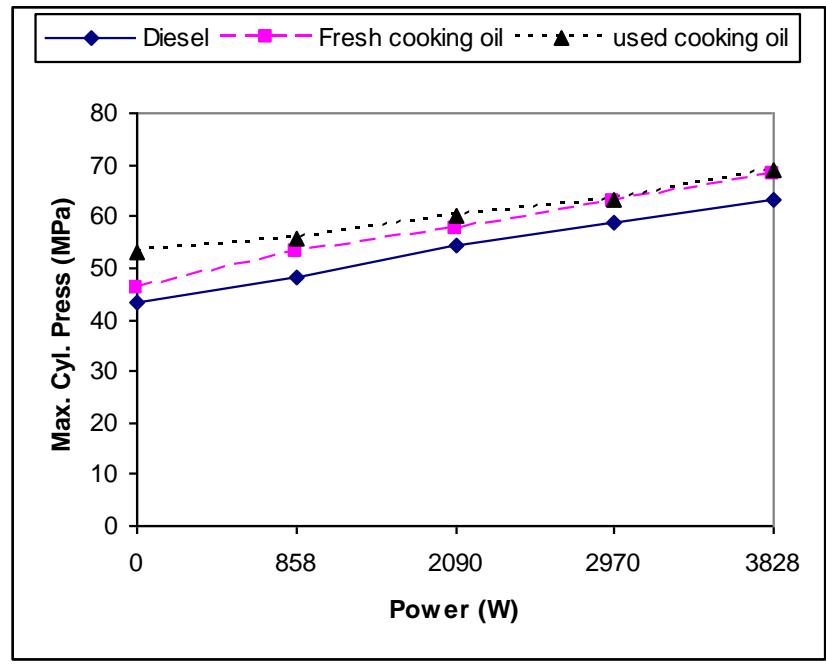

Figure (7): comparison of peak pressure for biodiesel and diesel fuel

\section{Conclusions:}

The properties of biodiesel from fresh and used cooking oil were found to be comparable to that of the diesel fuel.

The specific fuel consumption of the engine was increased in case of biodiesel.

The brake thermal efficiency of biodiesel is lower compared to that of diesel fuel.

The amount of $\mathrm{CO}$ emission was lower in case of biodiesel fuels than diesel fuel. Also the carbon dioxide emission was reduced with biodiesel from used cooking oil.

The peak pressure is slightly higher for biodiesel fuels when compared to that of diesel 


\section{References:}

[1] G Lakshmi Narayana Rao, S Sampath, K Rajagopal "Experimental Studies on the Combustion and Emission Characteristics of a Diesel Engine Fuelled with Used Cooking Oil Methyl Ester and its Diesel Blends" International Journal of Applied Science, Engineering and Technology 4;2 (C) www.waset.org Spring 2008

[2] M.K.Ghosal, D.K.Das, S.C.Pradhan and N.Sahoo "Performance Study of Diesel Engine by using Mahua Methyl Ester (biodiesel) and its Blends with Diesel Fuel" Agricultural Engineering International: the CIGR Ejournal. Manuscript EE 08014. Vol. X. October, 2008

[3] T. Venkateswara Rao a, G. Prabhakar Rao a, and K. Hema Chandra Reddy "Experimental Investigation of Pongamia, Jatropha and Neem Methyl Esters as Biodiesel on C.I. Engine" Jordan Journal of Mechanical and Industrial Engineering, Volume 2, Number 2, Jun. 2008, PP 117 - 122

[4] D. Ramesh and A. Sampathrajan. "Investigations on Performance and Emission Characteristics of Diesel Engine With Jatropha Biodiesel and Its Blends".

Agricultural Engineering International: the CIGR Ejournal. Manuscript EE 07013. Vol. X. March, 2008

[5] Jayant Singh, T. N. Mishra, T. K. Bhattacharya, and M. P. Singh, "Emission haracteristics of Methyl Ester of Rice Bran Oil as Fuel in Compression Ignition Engine" International Journal of Natural Sciences and Engineering 1:2 2008, PP $63-67$

[6] J. Van Gerpen, B. Shanks, and R. Pruszko, D. Clements, G. Knothe, "Biodiesel Production Technology" , National Renewable Energy Laboratory, subcontractor report, August 2002-January 2004) 